\title{
Postnatal Corticosteroids for Prevention and Treatment of Chronic Lung Disease in the Preterm Newborn
}

\author{
Sachin Gupta, ${ }^{1}$ Kaninghat Prasanth, ${ }^{1}$ Chung-Ming Chen, ${ }^{2,3,4}$ and Tsu F. Yeh ${ }^{3,4,5,6}$ \\ ${ }^{1}$ Department of Pediatrics, John Stroger Jr. Hospital of Cook County, Chicago, IL 60612, USA \\ ${ }^{2}$ Department of Pediatrics, Taipei Medical University Hospital, Taipei 110, Taiwan \\ ${ }^{3}$ Department of Pediatrics, School of Medicine, College of Medicine, Taipei Medical University, Taipei 110, Taiwan \\ ${ }^{4}$ Department of Pediatrics, China Medical University, Taichung 40402, Taiwan \\ ${ }^{5}$ Department of Pediatrics, Shuang Ho Hospital, Taipei Medical University, Taipei 110, Taiwan \\ ${ }^{6}$ Maternal Child Health Research Center, Taipei Medical University, Taipei 110, Taiwan
}

Correspondence should be addressed to Tsu F. Yeh, tsufuhy@yahoo.com

Received 1 June 2011; Accepted 25 July 2011

Academic Editor: Mei-Jy Jeng

Copyright (C) 2012 Sachin Gupta et al. This is an open access article distributed under the Creative Commons Attribution License, which permits unrestricted use, distribution, and reproduction in any medium, provided the original work is properly cited.

\begin{abstract}
Despite significant progress in the treatment of preterm neonates, bronchopulmonary dysplasia (BPD) continues to be a major cause of neonatal morbidity. Affected infants suffered from long-term pulmonary and nonpulmonary sequel. The pulmonary sequels include reactive airway disease and asthma during childhood and adolescence. Nonpulmonary sequels include poor coordination and muscle tone, difficulty in walking, vision and hearing problems, delayed cognitive development, and poor academic achievement. As inflammation seems to be a primary mediator of injury in pathogenesis of BPD, role of steroids as antiinflammatory agent has been extensively studied and proven to be efficacious in management. However, evidence is insufficient to make a recommendation regarding other glucocorticoid doses and preparations. Numerous studies have been performed to investigate the effects of steroid. The purpose of this paper is to evaluate these studies in order to elucidate the beneficial and harmful effects of steroid on the prevention and treatment of BPD.
\end{abstract}

\section{Introduction}

Despite significant progress in the treatment of preterm neonates, bronchopulmonary dysplasia (BPD) continues to be a major cause of neonatal morbidity. At earlier times, it was considered to be primarily iatrogenic in etiology as a consequence of crude ventilator techniques. In current time with advanced and sophisticated ventilator techniques, BPD continued to be a major sequel of neonatal respiratory distress syndrome (RDS), primarily because of better survival of extreme premature babies with other factors including ventilator-induced lung injury, exposure to oxygen, and inflammation. New bronchopulmonary dysplasia (new BPD) is characterized, in part, by arrested alveolar and vascular development of the immature lung [1]. Affected infants suffer from long-term pulmonary and nonpulmonary sequel. The pulmonary sequels include reactive airway disease and asthma during childhood and adolescence $[2,3]$.
Nonpulmonary long-term sequels include poor coordination and muscle tone, difficulty in walking, vision and hearing problems, delayed cognitive development, and poor academic achievement [4].

The proposed etiology of new BPD is the initiation of inflammatory mediators that cause impairment of alveolarization and vasculogenesis [5]. The lacking anti-inflammatory mediators in the preterm neonate may be inundated easily by the proinflammatory cascade. A difference in the release of pro- and anti-inflammatory cytokines, occurring as a result of intrauterine/postnatal infection (sepsis), ventilator trauma, oxidants, pulmonary edema, or sepsis, damages the immature lung.

As inflammation seems to be primary mediator of injury in pathogenesis of BPD, role of steroids as anti-inflammatory agent has been extensively studied and proven to be efficacious in management. But studies in last one and half decade have seriously questioned the routine use 
of steroids especially high-dose dexamethasone due to its long-term effect on neurodevelopment. In 2010, the American Academy of Pediatrics (AAP) revised policy statement regarding the use of postnatal corticosteroids for prevention or treatment of chronic lung disease in preterm infants, concluded that high-dose dexamethasone $(0.5 \mathrm{mg} / \mathrm{kg} /$ day $)$ does not seem to confer additional therapeutic benefit over lower doses, and is not recommended. Evidence is insufficient to make a recommendation regarding other glucocorticoid doses and preparations. The clinician must use clinical judgment when attempting to balance the potential adverse effects of glucocorticoid treatment with those of BPD. Postnatal use of dexamethasone for BPD has decreased since the publication of the AAP statement in 2002; however, the incidence of BPD has not decreased [6]. Instead, several reports have suggested that the incidence or severity of BPD may have increased. Despite AAP statement to limit the use of systemic dexamethasone especially high dose, seems reasonable considering it has proven adverse effect on neurodevelopment. But that cannot negate the fact that steroids do have beneficial effects on pulmonary physiology, and currently we do not have any other antiinflammatory of similar efficacy. If we can limit the systemic side effects of steroid in some way and can utilize its local anti-inflammatory effect on lung, it can be a very useful drug in management of new BPD.

Various mechanisms have been described for beneficial effect of steroids on lung mechanics in infants with BPD. Various steroids of different potency have been studied at various timings; in different dosing regimens; for different duration; in different forms (including intravenous, inhalational, intratracheal, and recently intratracheal with surfactant as a vehicle). Amongst systemically used steroids, dexamethasone comes as the most potent and most studied one. It has been studied in early ( $<7$ days), moderately early (7-14 days) and late/delayed (>14 days), postnatal periods and dosing ranging from $0.1 \mathrm{mg} / \mathrm{kg} /$ day to $0.5 \mathrm{mg} / \mathrm{kg} /$ day and duration ranging from 3 days to 42 days. Hydrocortisone comes second. Beclomethasone is the most commonly used inhalational steroid for BPD. Recently, budesonide has been tried as intratracheal instillation with or without surfactant as a vehicle and shown to reduce inflammatory marker in tracheal aspirates in initial clinical trials.

\section{Possible Mechanisms of Action of Glucocorticoids}

As the pathogenesis of BPD is multifactorial, so are the mechanisms to respond to steroid therapy. Since inflammation seems to play a critical role in the evolution of BPD, benefit seen with glucocorticoids most likely mediates through its anti-inflammatory effect.

The primary anti-inflammatory effect of glucocorticoids is mediated by annexin-1 synthesis. Annexin-1 suppresses phospholipase A2 expression, thereby blocking eicosanoids (i.e., prostaglandins, thromboxanes, prostacyclins, and leukotrienes) and the subsequent leukocyte inflammatory events including adhesion and migration. Thus, glucocorticoids inhibit two main products of inflammation prostaglandins and leukotrienes. In addition, glucocorticoids also suppress both cyclooxygenase I and II similar to NSAID, potentiating the anti-inflammatory effect [7].

Lung inflammation is downregulated by dexamethasone therapy. Groneck et al. evaluated the tracheobronchial aspirate from preterm infants at high risk of BPD. The number of neutrophils and concentrations of leukotriene B4, interleukin-1, elastase- $\alpha 1$-protease inhibitor, and albumin were decreased after dexamethasone treatment [8]. It indicates that dexamethasone affects the release of inflammatory mediators and neutrophils influx into the airways of preterm infants who require mechanical ventilation and decreases the microvascular permeability. Pulmonary edema is the hallmark of BPD; dexamethasone has been shown to reduce the pulmonary edema in infants with BPD.

Glucocorticoids block the release of arachidonic acids and its subsequent conversion to eicosanoids. The decreased incidence of patent ductus arteriosus (PDA) after prenatal or postnatal steroid therapy is likely due to the influence of the corticosteroid effect on the responsiveness of ductal tissue to prostaglandins. Prostaglandin has an important role in maintaining the integrity of gastrointestinal mucosa. The use of steroids may increase the risk of gastrointestinal perforation. Other mechanisms such as modulating the transcription and posttranscriptional regulation of surfactant component, stimulation of antioxidant production, and enhancement of adrenergic activities may also be responsible for the acute and rapid improvement of pulmonary function [9]. Unfortunately, some of these mechanisms are also involved in physiologic signaling other than inflammatory signaling; the therapeutic effects of glucocorticoids in inflammation are often accompanied by clinically significant side effects. Glucocorticoid receptors are present virtually in all cells. Prolonged or high-dose glucocorticoids therapy causes multiple systemic side effects. There is a consensus that the desired anti-inflammatory effects of glucocorticoids are mainly mediated via repression of gene transcription. In contrast, the underlying molecular mechanisms for glucocorticoids-mediated side effects are complex and partly understood.

\section{Postnatal Corticosteroid Therapy in Preterm Infants}

3.1. Choice of Glucocorticoids. Dexamethasone is a potent, long-acting steroid with exclusive glucocorticoid effect. When compared to hydrocortisone, dexamethasone is $25-50$ times more potent. The half-life is $36-54$ hours. Dexamethasone has been extensively studied in neonatal medicine and has shown to improve pulmonary function, facilitate extubation, and decrease the incidence of BPD [10-15]. However, many associated adverse side effects prevent the routine use of dexamethasone. The short-term side effects include hyperglycemia, hypertension, hypertrophic cardiomyopathy, gastrointestinal bleeding, and perforation. The risk 
of gastrointestinal perforation increases with concomitant indomethacin treatment [16]. There is also a concern with the chronic suppression of the hypothalamic-pituitaryadrenal axis [17, 18] and long-term neurodevelopmental delay $[19,20]$.

On the other hand, hydrocortisone has almost equal glucocorticoid and mineralocorticoid action, and the halflife is only 8 hours. Sick premature infants have relative adrenal insufficiency during acute illness because of developmental immaturity of the hypothalamic-pituitary-adrenal axis suggesting that an early physiological replacement of cortisol may be needed [21-24]. However, large doses above physiologic levels to achieve the anti-inflammatory action may cause significant mineralocorticoid side effects. Early use of hydrocortisone ( $<48$ hours) was shown to decrease the risk of PDA but increased survival only in infants exposed to maternal chorioamnionitis or who had low cortisol values $[22,23]$.

Another steroid betamethasone, a stereoisomer of dexamethasone, differs only in the orientation of the methyl group at position 16. However, this structural difference could be responsible for marked differences in nongenomic effects. Previous antenatal steroid studies have demonstrated that both drugs have the same effects in reducing the risk of intraventricular hemorrhage, but betamethasone has been shown to be more effective than dexamethasone in reducing the risk of neonatal death and cystic periventricular leukomalacia among very premature infants $[24,32]$. The study of betamethasone in postnatal use is limited. A recent study has shown that betamethasone is as effective as dexamethasone in improving pulmonary function, but with fewer adverse effects, such as poor weight gain and hyperglycemia [33].

Inhaled glucocorticoids have been used in neonates without concomitant systemic side effects. They have been successfully used for years in asthmatic patients, but their effects on mechanical ventilated preterm infants are less impressive. The delivery of inhaled glucocorticoids in preterm infants is technically difficult, and its effectiveness has been shown to be limited. Similarly, direct intratracheal instillation of glucocorticoids alone has also not been shown to be effective. A topical glucocorticoid aerosol (budesonide, fluticasone, or beclomethasone) is administered by metered dose inhaler and spacer directly to the endotracheal tube of intubated infants. In an animal model, delivery of beclomethasone to the lungs of an intubated neonate was only $1-2 \%$ of the original aerosolized drug [34]. The inhaled steroid did not decrease the incidence of BPD but improved blood gas, chest $\mathrm{X}$-ray score, and a decrease in the use of systemic steroids [35-38].

A recent study from Yeh et al. suggested that intratracheal instillation of budesonide, a strong local glucocorticoids, using surfactant as vehicle may effectively deliver the medication to the lung and may decrease the incidence of BPD [39].

3.2. Timing of Postnatal Steroid Use. The potential mechanism of glucocorticoids in premature infants with RDS is not exactly known. Most of the clinical trials only evaluated clin- ical responses and did not study mechanisms explaining the beneficial effects. Based on the pathologic and physiologic studies, it seems that steroid therapy given at different times may mediate physiologic effect via different mechanisms. Premature infants may develop lung injury shortly after birth and during the first 1-2 weeks after exposure to infection, oxygen, or positive pressure ventilation. Therefore, steroid should be given shortly after birth or during the first few weeks to prevent BPD via its anti-inflammatory action. On the other hand, steroid therapy given at 3-6 weeks of life may derive its benefits from the modulation of lung repair. Alternately, steroids given at any age may be effective in infants with BPD by blunting hyperreactivity and inflammation.

3.3. Dosage and Duration of Corticosteroids. Most recent studies used a dose of dexamethasone $0.1-0.5 \mathrm{mg} / \mathrm{kg} /$ day, equivalent to 10 to 20 times of endogenous corticosteroid levels, in durations ranging from 3 to 42 days. The high dosage and long duration of treatment might be responsible for the delay of brain growth and subsequent poor neurodevelopmental outcomes. A lower dose and shorter duration of dexamethasone may be beneficial and without significant side effects. However, the proper dosage and duration of treatment has not been well defined.

Compare to dexamethasone, the dosage of hydrocortisone used in the trials aimed to prevent BPD was smaller, ranging from $1-2 \mathrm{mg} / \mathrm{kg} / \mathrm{day}$, which is equivalent to 1 to 2 times the physiological level. Unfortunately, the low-dose replacement showed no reduction of BPD.

\section{Current Evidence of Steroid Use: AAP Revised Policy, 2010}

4.1. Dexamethasone. Current evidence suggests that dexamethasone may decrease mortality rates, facilitate extubation, and generally decrease the incidence of BPD but that it carries a significant risk for short- and long-term adverse effects, especially impairment of growth and neurodevelopment $[6,53-56]$.

(1) Cochrane database systemic review concluded that the benefits of dexamethasone therapy in the first week of life may not outweigh its many adverse effects [57]. In contrast, it concludes that treatment after the first postnatal week may reduce mortality rates without increasing adverse long-term neurodevelopmental outcomes although long-term follow-up data remain limited [58].

(2) Two other systemic meta-analyses have been done recently. In the first review, a risk-weighted metaanalysis, the authors emphasized the importance of the a priori risk of death or BPD in different study populations [59]. In this analysis, the incidence of death or cerebral palsy (CP) was increased among dexamethasone-treated infants compared with placebo-treated infants in studies that enrolled patients at low risk $(<35 \%)$ of BPD. In contrast, 
TABLE 1: RCTs of dexamethasone to prevent or treat BPD reported since 2001.

\begin{tabular}{|c|c|c|c|c|c|}
\hline $\begin{array}{l}\text { Study, no. of } \\
\text { centers }\end{array}$ & $n$ & $\begin{array}{l}\text { Eligibility criteria } \\
\text { (all on mechanical } \\
\text { ventilation) }\end{array}$ & Timing & $\begin{array}{l}\text { Dexamethasone dosing } \\
\text { regimen }\end{array}$ & Outcome \\
\hline $\begin{array}{l}\text { McEvoy et al. } \\
{[25], 1 \text { center }}\end{array}$ & 62 & $\begin{array}{l}500-1500 \text { g BW; } \\
\leq 32 \text { wk gestation }\end{array}$ & $7-21$ postnatal days & $\begin{array}{l}5 \mathrm{mg} / \mathrm{kg} / \text { day tapered over } 7 \\
\text { days versus } 0.2 \mathrm{mg} / \mathrm{kg} \text { tapered } \\
\text { over } 7 \text { days }\end{array}$ & $\begin{array}{l}\text { Rate of survival without BPD } \\
76 \% \text { versus } 73 \% \text { (NS); no } \\
\text { benefit to higher dose }\end{array}$ \\
\hline $\begin{array}{l}\text { Odd et al. } \\
{[26], 1 \text { center }}\end{array}$ & 33 & $\leq 1250 \mathrm{~g} \mathrm{BW}$ & $1-3$ wk of age & $\begin{array}{l}0.5 \mathrm{mg} / \mathrm{kg} / \text { day tapered over } 42 \\
\text { days versus "individualize" } \\
\text { (same dose, shorter course) }\end{array}$ & $\begin{array}{l}\text { Rate of survival without BPD: } \\
24 \% \text { versus } 30 \%(\mathrm{NS}) \text {; no } \\
\text { difference in } 18 \text {-month } \\
\text { outcomes }\end{array}$ \\
\hline $\begin{array}{l}\text { Malloy et al. } \\
\text { [27], } 1 \text { center }\end{array}$ & 16 & $\begin{array}{l}<1501 \text { g BW; } \\
<34 \text { wk gestation }\end{array}$ & $<28$ postnatal days & $\begin{array}{l}0.5 \mathrm{mg} / \mathrm{kg} / \text { day tapered over } 7 \\
\text { days versus } 0.08 \mathrm{mg} / \mathrm{kg} / \text { day for } \\
7 \text { days }\end{array}$ & $\begin{array}{l}\text { Rate of survival without BPD: } \\
11 \% \text { versus } 38 \% \text { (NS); higher } \\
\text { dose had more adverse effects, } \\
\text { no apparent benefit }\end{array}$ \\
\hline $\begin{array}{l}\text { Walther et al. } \\
{[28], 1 \text { center }}\end{array}$ & 36 & $\begin{array}{l}\geq 600 \mathrm{~g} \mathrm{BW} \\
24-32 \text { wk gestation }\end{array}$ & 7-14 d postnatal age & $\begin{array}{l}0.2 \mathrm{mg} / \mathrm{kg} / \text { day tapered over } 14 \\
\text { days versus placebo }\end{array}$ & $\begin{array}{l}\text { Rate of survival without BPD: } \\
65 \% \text { versus } 47 \%(\mathrm{NS}) ; \\
\text { extubation: } 76 \% \text { versus } 42 \% \\
(P<.05)\end{array}$ \\
\hline $\begin{array}{l}\text { Anttila et al. } \\
{[29], 6} \\
\text { centers }\end{array}$ & 109 & $\begin{array}{l}500-999 \text { g BW; } \\
\leq 31 \text { wk gestation }\end{array}$ & Eligible at $4 \mathrm{~h}$ of age & $\begin{array}{l}0.25 \mathrm{mg} / \mathrm{kg} \text { every } 12 \mathrm{~h} \times 4 \\
\text { doses versus placebo }\end{array}$ & $\begin{array}{l}\text { Rate of survival without BPD: } \\
58 \% \text { versus } 52 \% \text { (NS) }\end{array}$ \\
\hline $\begin{array}{l}\text { Doyle et al. } \\
{[30], 11} \\
\text { centers }\end{array}$ & 70 & $\begin{array}{l}<1000 \text { g BW } \\
<28 \text { wk gestation }\end{array}$ & $>1$ wk postnatal age & $\begin{array}{l}0.25 \mathrm{mg} / \mathrm{kg} \text { every } 12 \mathrm{~h} \times 4 \\
\text { doses versus placebo }\end{array}$ & $\begin{array}{l}\text { Rate of survival without BPD: } \\
14 \% \text { versus } 9 \%(\mathrm{NS}) ; \\
\text { extubation: } 60 \% \text { versus } 12 \% \\
\text { (odds ratio: } 11.2(95 \% \\
\text { confidence interval: } 3.2-39.0) \text { ) }\end{array}$ \\
\hline $\begin{array}{l}\text { Rozycki et al. } \\
{[31], 1 \text { center }}\end{array}$ & 61 & 650-2000 g BW & $\geq 14$ day postnatal age & $\begin{array}{l}0.5 \mathrm{mg} / \mathrm{kg} / \text { day tapered over } 42 \\
\text { day versus inhaled } \\
\text { beclomethasone at } 3 \text { different } \\
\text { doses for } 7 \text { days followed by } \\
\text { the above-listed } \\
\text { dexamethasone course, if still } \\
\text { mechanically ventilated }\end{array}$ & $\begin{array}{l}\text { Rate of survival without BPD: } \\
53 \% \text { versus } 46 \%(\mathrm{NS}) \text {; } \\
\text { extubation by } 7 \mathrm{~d}: 7 \text { of } 15 \\
\text { versus } 6 \text { of } 46(P<.01)\end{array}$ \\
\hline
\end{tabular}

BW = body weight; NS = not significant.

dexamethasone treatment decreased the risk of death or $\mathrm{CP}$ when infants at high risk of BPD $(\geq 65 \%)$ were studied [59]. Thus, for infants at the highest risk of BPD, the beneficial effect of dexamethasone in reducing lung disease seemed to outweigh its adverse effect of increasing the risk of CP. In the second meta-analysis, the authors compared outcomes for trials with different cumulative doses of dexamethasone and concluded that a higher cumulative dose improved rates of survival without BPD and did not increase adverse long-term effects [60].

(3) Small individual randomized controlled trials (RCTs) that directly compared high-versus lowdexamethasone doses, variably defined, have revealed no differences in efficacy (Table 1) [25-27]. These studies have generally been small and heterogeneous, which makes them difficult to compare.

(4) Three RCTs have compared dexamethasone to placebo (Table 1 ); 1 was small and the other 2 were stopped early and are, therefore, underpowered [2830]. One trial compared an early, short course of dexamethasone to placebo and revealed no significant difference in mortality or BPD rates [29]. The other 2 trials evaluated the efficacy of a later, lowerdose course of dexamethasone for facilitating extubation, and the authors reported that significantly more dexamethasone-treated infants were successfully extubated during the treatment period $[28,30]$. Similar results were reported from an additional study that compared systemic dexamethasone to inhaled beclomethasone for extubation; significantly more dexamethasone-treated infants were successfully extubated within 7 days (Table 1) [31]. These extubation trials were not powered to evaluate the effect of the treatment on rates of survival without BPD.

(5) Many short-term adverse effects of dexamethasone therapy have been described; however, the main reason for the decline in its use is an adverse effect on neurodevelopment, particularly higher rates of CP. Eleven RCTs have been done to evaluate long term neurodevelopmental outcome (Table 2) [25, 40-48]. 
TABLE 2: Neurodevelopmental follow-up of dexamethasone RCTs reported after 2001.

\begin{tabular}{|c|c|c|c|c|}
\hline $\begin{array}{l}\text { Study, planned } \\
\text { age at followup }\end{array}$ & $\begin{array}{l}\text { Followup, } \% \text { (no. } \\
\text { of infants seen) }\end{array}$ & Treatment start time & Dexamethasone dosing regimen & $\begin{array}{l}\text { Primary neurodevelopmental } \\
\text { findings }\end{array}$ \\
\hline $\begin{array}{l}\text { McEvoy et al. } \\
{[25], 1 \text { year }}\end{array}$ & $66(39)$ & At $7-21$ days & $\begin{array}{l}\text { High versus low dose: } 7 \text {-day } \\
\text { taper from } 0.5 \mathrm{mg} / \mathrm{kg} / \text { day versus } \\
0.2 \mathrm{mg} / \mathrm{kg} / \text { day }\end{array}$ & $\begin{array}{l}\text { MDI < 70: } 24 \% \text { (high) versus } \\
\text { 17\% (low) }(\mathrm{NS}) ; \\
\text { CP: } 10 \% \text { versus } 11 \%(\mathrm{NS})\end{array}$ \\
\hline $\begin{array}{l}\text { Armstrong et al. } \\
\text { [40], } 18 \text { months } \\
\text { chronological } \\
\text { age }\end{array}$ & $96(64)$ & On day 7 & 42-d taper versus 3 -day pulse & $\begin{array}{l}\text { No difference in } 18 \text {-month } \\
\text { outcomes } \\
\text { No disability: } 34 \% \text { versus } 31 \% \\
\text { (NS) }\end{array}$ \\
\hline $\begin{array}{l}\text { Doyle et al. }[41] \text {, } \\
2 \text { years } \\
\text { corrected age }\end{array}$ & $98(58)$ & After 7 days & $\begin{array}{l}0.15 \mathrm{mg} / \mathrm{kg} / \text { day tapered over } 10 \\
\text { days }\end{array}$ & $\begin{array}{l}\text { Death or major disability: } 46 \% \\
\text { versus } 43 \%(\mathrm{NS}) \text {; death or CP: } \\
23 \% \text { versus } 37 \%(\mathrm{NS}) \text {; CP: } 14 \% \\
\text { versus } 22 \%(\mathrm{NS}) \text {; major } \\
\text { disability } 41 \% \text { versus } 31 \%(\mathrm{NS})\end{array}$ \\
\hline $\begin{array}{l}\text { Stark et al. [ } 42] \text {, } \\
18-22 \text { months } \\
\text { corrected age }\end{array}$ & $74(123)$ & On day 1 & $\begin{array}{l}0.15 \mathrm{mg} / \mathrm{kg} / \text { day tapered over } 7 \\
\text { days }\end{array}$ & $\begin{array}{l}\text { MDI < 70: } 51 \% \text { versus } 43 \% \\
\text { (NS); PDI < } 70: 30 \% \text { versus } 35 \% \\
\text { (NS); abnormal neurologic } \\
\text { exam: } 25 \% \text { each group }\end{array}$ \\
\hline $\begin{array}{l}\text { Romagnoli et al. } \\
{[43], 3 \text { years }}\end{array}$ & $100(30)$ & On day 4 & $0.5 \mathrm{mg} / \mathrm{kg} /$ day tapered over $1 \mathrm{wk}$ & $\begin{array}{l}\text { No differences in any parameter; } \\
\text { CP: } 9 \% \text { versus } 14 \% \text { (NS) }\end{array}$ \\
\hline $\begin{array}{l}\text { Wilson et al. } \\
{[44], 7 \text { years }}\end{array}$ & $84(127)$ & Before 3 days & $\begin{array}{l}4 \text { groups: } 0.5 \mathrm{mg} / \mathrm{kg} / \text { day tapered } \\
\text { over } 12 \text { days versus late ( } 15 \text { days) } \\
\text { selective, versus inhaled early or } \\
\text { late selective }\end{array}$ & $\begin{array}{l}\text { No difference in cognitive, } \\
\text { behavioral, } \mathrm{CP} \text {, or combined } \\
\text { outcomes }\end{array}$ \\
\hline $\begin{array}{l}\text { Yeh et al. }[45] \text {, } \\
\text { school age } \\
\text { (mean: } 8 \text { years) }\end{array}$ & $92(146)$ & On day 1 & $\begin{array}{l}0.5 \mathrm{mg} / \mathrm{kg} / \text { day for } 1 \mathrm{wk} \text {, then } \\
\text { tapered for a total of } 28 \text { days }\end{array}$ & $\begin{array}{l}\text { Treated children were shorter } \\
(P=.03) \text {, had smaller head } \\
\text { circumference }(P=.04) \text {, lower } \\
\text { IQ scores }(P=.008) \text {, and more } \\
\text { significant disabilities }(\mathrm{CP}, \mathrm{IQ}< \\
\text { 5th percentile, vision or hearing } \\
\text { impairment }): 39 \% \text { versus } 22 \% \\
(P=.04)\end{array}$ \\
\hline $\begin{array}{l}\text { O'Shea et al. } \\
\text { [46], 4-11 years }\end{array}$ & $89(84)$ & On day $15-25$ & $\begin{array}{l}0.5 \mathrm{mg} / \mathrm{kg} / \text { day tapered over } 42 \\
\text { days versus placebo }\end{array}$ & $\begin{array}{l}\text { Death or major NDI: } 47 \% \text { versus } \\
41 \%(\mathrm{NS}) \text {; major NDI alone: } \\
36 \% \text { versus } 14 \%(P=.01)\end{array}$ \\
\hline $\begin{array}{l}\text { Gross et al. [47], } \\
15 \text { years }\end{array}$ & $100(22)$ & On day 14 & $\begin{array}{l}0.5 \mathrm{mg} / \mathrm{kg} / \text { day tapered over } 42 \\
\text { days versus } 18 \text {-day taper versus } \\
\text { placebo }\end{array}$ & $\begin{array}{l}\text { Intact survival (IQ }>70 \text {, normal } \\
\text { neurologic exam, regular } \\
\text { classroom): } 69 \% \text { versus } 25 \% \\
\text { (18-d course) versus } 18 \% \\
\text { (placebo) }(P<.05)\end{array}$ \\
\hline $\begin{array}{l}\text { Jones and the } \\
\text { Collaborative } \\
\text { Dexamethasone } \\
\text { Trial Follow-up } \\
\text { Group [48], } \\
\text { 13-17 years }\end{array}$ & $95(150)$ & At $2-12 \mathrm{wk}$ & $0.5 \mathrm{mg} / \mathrm{kg} /$ day for 7 days & $\begin{array}{l}\text { No difference in moderate/severe } \\
\text { disability (defined as IQ > } 2 \text { SDs } \\
\text { < mean, CP, hearing or vision } \\
\text { loss); CP: } 24 \% \text { versus } 15 \% \\
\text { (relative risk: } 1.58 \text { [ } 95 \% \\
\text { confidence interval: } 0.81-3.07] \text { ) }\end{array}$ \\
\hline
\end{tabular}

NDI: neurodevelopmental impairment; PDI: psychomotor developmental index; NS: not significant.

The heterogeneity of these reports makes it problematic to combine them meaningfully. Some studies did not reveal adverse effects on neurodevelopmental outcomes at various ages, whereas others did. Most of the studies were small, which reduced their ability to either prove or disprove causation. Two RCTs that used low doses of dexamethasone revealed no significant increase in $\mathrm{CP}$ or other neurodevelopmental impairments when compared with placebo. Because only a total of 96 dexamethasone-treated infants were evaluated in these studies, the results must be interpreted with caution $[41,42]$.

(6) Cohort studies of dexamethasone have revealed an association of its use with impaired neurodevelopmental outcomes [48, 61]; however, such an association cannot be construed as definitive evidence of harm. A clinician's decision to use a therapy 
incorporates numerous undocumented factors and varies from one clinician to the next, which may seriously confound the interpretation of such studies. Patients who receive dexamethasone for BPD are likely to be perceived as having more severe respiratory disease than infants who are not treated; such infants may have worse overall outcomes regardless of dexamethasone therapy.

(7) Authors of small series have also reported that infants treated with dexamethasone have more abnormalities on MRI than those not treated; again, causation cannot be attributed in the absence of an RCT [61, 62]. Two previously reported RCTs revealed more cranial ultrasound abnormalities in dexamethasonetreated infants compared with those treated with placebo, but the patient numbers were quite small $[63,64]$.

In summary, high daily doses of dexamethasone have been linked frequently to adverse neurodevelopmental outcomes, and this therapy is discouraged. Because an increase in adverse neurodevelopmental outcomes in treatment studies that used low doses of dexamethasone has not been reported, further studies of low-dose dexamethasone to facilitate extubation are warranted.

\subsection{Hydrocortisone.}

(1) Four RCTs designed to evaluate the ability of early hydrocortisone therapy to improve rates of survival without BPD have been done in recent times (Table 3) [49-52]. These studies were based on the premise that extremely preterm infants may have immature adrenal gland function, predisposing them to a relative adrenal insufficiency and inadequate anti-inflammatory capability during the first several weeks of life [21, 65-68]. In contrast to the heterogeneous nature of previous dexamethasone trials, these studies were similar in design, time of initiation, duration, and dose. The direction of effect favored the hydrocortisone-treated infants in all 4 studies, and a significant increase in rate of survival without BPD in the hydrocortisone-treated infants was reported for 2 of the studies. The largest trial $(n=360)$ did not reveal a significant benefit of hydrocortisone treatment in the overall study group; however, for infants exposed to prenatal inflammation $(n=149)$, identified before the trial as a specific group for analysis, hydrocortisone treatment resulted in a significant decrease in mortality rate and an increase in rate of survival without BPD [50]. Patient enrollment was halted early in 3 of these 4 studies because of a significant increase in spontaneous gastrointestinal perforation discovered in the largest trial [50], a complication also observed with early dexamethasone $[68,69]$. The perforations may have resulted from an interaction between high endogenous cortisol concentrations and indomethacin therapy in the first 48 hours; however, because administration of indomethacin was not randomized, this hypothesis remains to be tested.

(2) Neurodevelopmental outcomes at 18 to 22 months' corrected age have been published for 3 of these trials, and no adverse effects of hydrocortisone treatment were found [70, 71]. In the largest multicenter trial, the incidence of death or major neurodevelopmental impairment (52\% (hydrocortisone-treated) versus 56\% (placebo)), major neurodevelopmental impairment alone (39\% versus 44\%), and CP (16\% versus $18 \%$ ) was similar [70]. The only significant findings favored the hydrocortisone-treated group and included a decreased incidence of a Bayley Scales of Infant Development (2nd edition) Mental Developmental Index (MDI) 2 SDs below the mean (MDI < 70, 27\% versus 37\%; odds ratio: 0.47 (95\% confidence interval: $0.25-0.87)$ ) and a higher incidence of awareness of object permanence (an early test of working memory and prefrontal executive function) (89\% versus 79\%; odds ratio: 2.19 (95\% confidence interval: 1.06-4.52)).

(3) Hydrocortisone therapy given to facilitate extubation has been studied in cohort studies. In the first reported study, 25 infants treated with hydrocortisone at 1 hospital $(5 \mathrm{mg} / \mathrm{kg}$ per day, tapered over 3 weeks) were compared with 25 untreated infants at the same hospital and additionally with a cohort of 23 infants treated with dexamethasone $(0.5 \mathrm{mg} / \mathrm{kg}$ per day, tapered over 3 weeks) at a separate hospital [72]. The investigators found that hydrocortisone was as effective as dexamethasone in weaning infants from the ventilator and in decreasing supplemental oxygen therapy, with fewer short-term adverse effects. Followup of these children at school age revealed no differences in neurodevelopmental outcomes between hydrocortisone-treated infants and their comparison group, whereas dexamethasone-treated infants more often had an abnormal neurologic examination and less favorable school performance than their comparison cohort [72-75]. Subsequently, several large cohort studies from the same institution reported that although hydrocortisone-treated children were younger, smaller, and sicker than their untreated comparison groups, there were no adverse effects of hydrocortisone treatment on IQ, visual motor integration, memory testing, $\mathrm{CP}$, or findings on MRI [74-76]. Investigators from this institution have also reported that neonatal dexamethasone but not hydrocortisone therapy resulted in long-lasting changes in hypothalamic-pituitary-adrenal axis and T-cell function [77].

4.3. Differences between Dexamethasone and Hydrocortisone. As discussed before, many RCTs have shown adverse neurodevelopmental outcomes after postnatal dexamethasone treatment for BPD, but neither multicenter RCTs nor cohort 
TABLE 3: RCTs of early hydrocortisone to prevent BPD.

\begin{tabular}{|c|c|c|c|c|c|}
\hline $\begin{array}{l}\text { Study, no. of } \\
\text { centers }\end{array}$ & $n$ & $\begin{array}{c}\text { Population: mechanically } \\
\text { ventilated infants }\end{array}$ & Timing & $\begin{array}{l}\text { Hydrocortisone } \\
\text { dosing regimen }\end{array}$ & $\begin{array}{c}\text { Rate of survival } \\
\text { without BPD HC } \\
\text { versus placebo, \% }\end{array}$ \\
\hline $\begin{array}{l}\text { Watterberg et al. } \\
\text { [49], } 2 \text { centers }\end{array}$ & 40 & BW: 500-999g & $<48 \mathrm{~h}$ postnatal age & $\begin{array}{l}0.5 \mathrm{mg} / \mathrm{kg} \text { every } 12 \mathrm{~h} \\
\text { for } 9 \text { days } \\
0.25 \mathrm{mg} / \mathrm{kg} \text { every } 12 \mathrm{~h} \\
\text { for } 3 \text { days }\end{array}$ & 60 versus $35(P=.04)$ \\
\hline $\begin{array}{l}\text { Watterberg et al. } \\
{[50], 9 \text { centers }}\end{array}$ & 360 & BW: 500-999g & $<48 \mathrm{~h}$ postnatal age & $\begin{array}{c}0.5 \mathrm{mg} / \mathrm{kg} \text { every } 12 \mathrm{~h} \\
\text { for } 12 \text { days } \\
0.25 \mathrm{mg} / \mathrm{kg} \text { every } 12 \mathrm{~h} \\
\text { for } 3 \text { days }\end{array}$ & $\begin{array}{l}35 \text { versus } 34 \text { (OR: } 1.20 \\
(95 \% \text { CI: } 0.72-1.99))\end{array}$ \\
\hline $\begin{array}{l}\text { Peltoniemi et al. } \\
{[51], 3 \text { centers }}\end{array}$ & 51 & BW: 501-1250 g & $<36 \mathrm{~h}$ postnatal age & $\begin{array}{c}2.0 \mathrm{mg} / \mathrm{kg} / \text { day tapered } \\
\text { to } 0.75 \mathrm{mg} / \mathrm{kg} / \text { day over } \\
10 \text { days }\end{array}$ & $\begin{array}{c}64 \text { versus } 46 \text { (OR: } 1.48 \\
(95 \% \text { CI: } 0.49-4.48))\end{array}$ \\
\hline $\begin{array}{l}\text { Bonsante et al. } \\
{[52], 2 \text { centers }}\end{array}$ & 50 & BW: 500-1249 g & $<48 \mathrm{~h}$ postnatal age & $\begin{array}{l}0.5 \mathrm{mg} / \mathrm{kg} \text { every } 12 \mathrm{~h} \\
\text { for } 9 \text { days; } \\
0.25 \mathrm{mg} / \mathrm{kg} \text { every } 12 \mathrm{~h} \\
\text { for } 3 \text { days }\end{array}$ & 64 versus $32(P<.05)$ \\
\hline
\end{tabular}

studies have revealed adverse effects on functional or structural neurologic outcomes after neonatal hydrocortisone therapy. Possible reasons could be as follows.

(1) Dissimilar effective glucocorticoid dose-neonatal animal studies have consistently revealed adverse effects on brain growth after high doses of glucocorticoid $[78,79]$, and results of evaluation of 22 patients who received high-dose hydrocortisone in a study from the early 1970 s were suggestive of harm [80, 81]. High-dose dexamethasone $(0.5 \mathrm{mg} / \mathrm{kg}$ per day) is equivalent to at least 15 to $20 \mathrm{mg} / \mathrm{kg}$ per day of hydrocortisone [82], far higher than the doses of hydrocortisone given in the recent studies described previously. Low-dose dexamethasone (0.1$0.15 \mathrm{mg} / \mathrm{kg}$ per day) may be equivalent to 3 to $6 \mathrm{mg} / \mathrm{kg}$ per day of hydrocortisone; however, because of its much longer biological half-life, it could have a much higher relative potency [83]. Lowering the dose of dexamethasone may, therefore, decrease its adverse effects, as is suggested by the 2 studies of outcome after lower-dose dexamethasone therapy $[41,42]$.

(2) There are dissimilar effects of these agents on the hippocampus, an area of the brain critical to learning, memory, and spatial processing $[84,85]$. The hippocampus contains a high density of both mineralocorticoid and glucocorticoid receptors [86, 87]. Hydrocortisone, which is identical to native cortisol, can bind to both classes of receptors. In contrast, dexamethasone binds only to glucocorticoid receptors, which, in animal models, has been shown to result in degeneration and necrosis of hippocampal neurons $[88,89]$. This effect of dexamethasone is blocked by simultaneous administration of corticosterone (the cortisol equivalent in the rat) [88]. In humans, neonatal treatment with dexamethasone, but not hydrocortisone, has been shown to alter hippocampal synaptic plasticity and associative memory formation in later life [90]. Dexamethasone exposure has also been linked to decreased hippocampal volume in 1 cohort study [91, 92], but cohort studies of infants treated with hydrocortisone have revealed no decrease in hippocampal volume [74], no adverse effect on hippocampal metabolism, and no adverse effect on memory at school age [76] when compared with a larger, more mature group of nontreated infants.

Whatever the underlying explanation(s) for the observed differences in short- and long-term outcomes may be, further RCTs are needed to answer the many remaining questions, including whether lower doses of dexamethasone can avoid previously observed adverse effects, whether hydrocortisone is efficacious for extubation, whether specific groups of infants may derive particular benefit from hydrocortisone therapy, and whether the incidence of spontaneous gastrointestinal perforation during early glucocorticoid administration can be decreased by avoiding concomitant indomethacin or ibuprofen therapy and/or by monitoring cortisol concentrations.

4.4. Other Glucocorticoids (Systemic). No available evidence support use of other systemic glucocorticoids, such as prednisone or methylprednisolone, to treat or prevent BPD.

4.5. Inhaled Glucocorticoids. Although some tertiary care Neonatal ICUs routinely use inhaled beclomethasone for BPD babies, no available evidence support the efficacy of inhaled glucocorticoids to prevent or decrease the severity of BPD. Recent Cochrane database systemic review concluded "there is no evidence that inhaling steroids prevent chronic lung disease or the number of days the baby needed breathing support and additional oxygen" $[93,94]$.

Beclomethasone and flunisolide have been studied by nebulization in view of decreasing need for systemic steroid and side effects. The early postnatal administration of 
inhaled steroid to prevent BPD was studied in a large randomized, multicenter trial [34]. In this study, 253 infants with a gestation age of $<33$ weeks, a birth weight of $<1250 \mathrm{~g}$, and who were mechanically ventilated at 3 to 14 days of age were randomly assigned to inhaled beclomethasone or a placebo for four weeks. The need for supplemental oxygen was similar in the beclomethasone and placebo groups at 28 days of life and 36 weeks postmenstrual age. In this study, beclomethasone therapy did not prevent BPD; however, it significantly reduced the use of systemic glucocorticoid therapy and mechanical ventilation at 28 days of age. In a small study, fluticasone propionate inhalation was given for 3 weeks to premature infants (less than 32 weeks) with moderate BPD (required fraction of inspired oxygen $>0.25$ or mechanical ventilation) at 28-60 days. There was no difference between infants treated with inhaled fluticasone versus placebo in the duration of oxygen therapy or ventilatory support [32].

4.6. Direct Intratracheal Instillation (IT) of Steroid with or without Surfactant as a Vehicle. Aerosolized drugs may be ineffective in preterm infants as very little drug is delivered to the lung, thereby limiting its effects. Novel idea of using surfactant as a vehicle to administer budesonide has been under study. A recent study by Halliday et al. demonstrated that intratracheal instillation of budesonide using surfactant as a vehicle significantly decreased the combined outcome of death and CLD without apparent immediate and longterm adverse effects [56]. Budesonide is a strong topical antiinflammatory glucocorticoid. It can be effectively delivered to the lungs and remain in the lungs for some time after intratracheal instillation. Once absorbed, it can be rapidly metabolized to metabolites of low glucocorticoid effect. However, before this regimen can be recommended, a large sample trial is needed.

\section{Current Evidence-Based Recommendations (AAP Revised Policy Statement, 2010)}

(1) High daily doses of dexamethasone (approximately $0.5 \mathrm{mg} / \mathrm{kg}$ per day) have been shown to reduce the incidence of BPD but have been associated with numerous short- and long-term adverse outcomes, including neurodevelopmental impairment, and at present, there is no basis for postulating that high daily doses confer additional therapeutic benefit over lower-dose therapy.

Recommendation. In the absence of randomized trial results showing improved short- and long-term outcomes, therapy with high-dose dexamethasone cannot be recommended.

(2) Low-dose dexamethasone therapy $(<0.2 \mathrm{mg} / \mathrm{kg}$ per day) may facilitate extubation and may decrease the incidence of short- and long-term adverse effects observed with higher doses of dexamethasone. Additional RCTs sufficiently powered to evaluate the effects of low-dose dexamethasone therapy on rates of survival without BPD, as well as on other shortand long-term outcomes, are warranted.

Recommendation. There is insufficient evidence to make a recommendation regarding treatment with low-dose dexamethasone.

(3) Low-dose hydrocortisone therapy ( $1 \mathrm{mg} / \mathrm{kg}$ per day) given for the first 2 weeks of life may increase rates of survival without BPD, particularly for infants delivered in a setting of prenatal inflammation, without adversely affecting neurodevelopmental outcomes. Clinicians should be aware of a possible increased risk of isolated intestinal perforation associated with early concomitant treatment with inhibitors of prostaglandin synthesis. Further RCTs powered to detect effects on neurodevelopmental outcomes, aimed at targeting patients who may derive most benefit and developing treatment strategies to reduce the incidence of isolated intestinal perforation, are warranted.

Recommendation. Early hydrocortisone treatment may be beneficial in a specific population of patients; however, there is insufficient evidence to recommend its use for all infants at risk of BPD.

(4) Higher doses of hydrocortisone (3-6 mg/kg per day) instituted after the first week of postnatal age have not been shown to improve rates of survival without BPD in any RCT. RCTs powered to assess the effect of this therapy on short- and long-term outcomes are needed.

Recommendation. Existing data are insufficient to make a recommendation regarding treatment with high-dose hydrocortisone.

\section{Summary}

BPD is the disease of very low birth weight and extremely low birth weight newborns with multifactorial etiology including prematurity itself, ventilator-induced injury, oxygen, and inflammation. BPD has long-term adverse pulmonary and neurodevelopment outcome. Steroids usage for treatment of BPD also has been shown to have adverse neurodevelopmental outcome. Available data are conflicting and inconclusive; clinicians must use their own clinical judgment to balance the adverse effects of BPD with the potential adverse effects of treatments for each individual patient. Very low birth weight infants who remain on mechanical ventilation after 1 to 2 weeks of age are at very high risk of developing BPD [58]. When considering corticosteroid therapy for such an infant, clinicians might conclude that the risks of a short course of glucocorticoid therapy to mitigate BPD are warranted [59]. This individualized decision should be made in conjunction with the infant's parents. 


\section{Acknowledgment}

This work was supported in part by the National Health Research Institute, Taiwan (NHRI-EX99-9818PI).

\section{References}

[1] A. Bhandari and V. Bhandari, "Bronchopulmonary dysplasia: an update," Indian Journal of Pediatrics, vol. 74, no. 1, pp. 7377, 2007.

[2] A. Bhandari and V. Bhandari, "Pathogenesis, pathology and pathophysiology of pulmonary sequelae of bronchopulmonary dysplasia in premature infants," Frontiers in Bioscience, vol. 8, pp. e370-380, 2003.

[3] A. Bhandari and H. B. Panitch, "Pulmonary outcomes in bronchopulmonary dysplasia," Seminars in Perinatology, vol. 30, no. 4, pp. 219-226, 2006.

[4] P. J. Anderson and L. W. Doyle, "Neurodevelopmental outcome of bronchopulmonary dysplasia," Seminars in Perinatology, vol. 30, no. 4, pp. 227-232, 2006.

[5] C. T. D'Angio and W. M. Maniscalco, "The role of vascular growth factors in hyperoxia-induced injury to the developing lung," Frontiers in Bioscience, vol. 7, pp. 1609-1623, 2002.

[6] American Academy of Pediatrics, Committee on Fetus and Newborn, Canadian Paediatric Society, Fetus, and Newborn Committee, "Postnatal corticosteroids to treat or prevent chronic lung disease in preterm infants," Pediatrics, vol. 109, pp. 330-338, 2002.

[7] T. Rhen and J. A. Cidlowski, "Antiinflammatory action of glucocorticoids-new mechanisms for old drugs," The New England Journal of Medicine, vol. 353, no. 16, pp. 1711-1723, 2005.

[8] P. Groneck, D. Reuss, B. Gotze-Speer, and C. P. Speer, "The effects of dexamethasone on chemotactic activity and inflammatory mediators intracheobroncheal aspirates of preterm infants at risk for chronic lung disease," Journal of Pediatrics, vol. 122, no. 6, pp. 938-944, 1993.

[9] P. C. Ng, "The effectiveness and side effect of dexamethasone in preterm infants with bronchopulmonary dysplasia," Archives of Disease in Childhood, vol. 68, no. 3, pp. 330-336, 1993.

[10] G. B. Avery, A. B. Fletcher, M. Kaplan, and D. S. Brudno, "Controlled trial of dexamethasone in respirator-dependent infants with bronchopulmonary dysplasia," Pediatrics, vol. 75, no. 1, pp. 106-111, 1985.

[11] J. J. Cummings, D. B. D’Eugenio, and S. J. Gross, “A controlled trial of dexamethasone in premature infants at high risk for bronchopulmonary dysplasia," The New England Journal of Medicine, vol. 320, no. 23, pp. 1505-1510, 1989.

[12] T. F. Yeh, J. A. Torre, A. Rastogi, M. A. Anyebuno, and R. S. Pildes, "Early postnatal dexamethasone therapy in premature infants with severe respiratory distress syndrome: a doubleblind, controlled study," Journal of Pediatrics, vol. 117, no. 2, pp. 273-282, 1990.

[13] A. Rastogi, S. M. Akintorin, M. L. Bez, P. Morales, and R. S. Pildes, "A controlled trial of dexamethasone to prevent bronchopulmonary dysplasia in surfactant-treated infants," Pediatrics, vol. 98, no. 2, pp. 204-210, 1996.

[14] T. F. Yeh, Y. J. Lin, W. S. Hsieh et al., "Early postnatal dexamethasone therapy for the prevention of chronic lung disease in preterm infants with respiratory distress syndrome: a multicenter clinical trial," Pediatrics, vol. 100, no. 4, p. e3, 1997.
[15] J. S. Garland, C. P. Alex, T. H. Pauly et al., "A three-day course of dexamethasone therapy to prevent chronic lung disease in ventilated neonates: a randomized trial," Pediatrics, vol. 104, no. 1 I, pp. 91-99, 1999.

[16] A. R. Stark, W. A. Carlo, J. E. Tyson et al., "Adverse effects of early dexamethasone in extremely-low-birth-weight infants: National Institute of Child Health and Human Development Neonatal Research Network," The New England Journal of Medicine, vol. 344, pp. 95-101, 2001.

[17] Z. B. Rizvi, H. S. Aniol, T. F. Myers, W. P. Zeller, S. G. Fisher, and C. L. Anderson, "Effects of dexamethasone on the hypothalamic-pituitary-adrenal axis in preterm infants," Journal of Pediatrics, vol. 120, no. 6, pp. 961-965, 1992.

[18] R. Karemaker, A. Kavelaars, M. T. Wolbeek et al., "Neonatal dexamethasone treatment for chronic lung disease of prematurity alters the hypothalamus-pituitary-adrenal axis and immune system activity at school age," Pediatrics, vol. 121, no. 4, pp. e870-e878, 2008.

[19] T. F. Yeh, Y. J. Lin, C. C. Huang et al., "Early dexamethasone therapy in preterm infants: a follow-up study," Pediatrics, vol. 101, no. 5, p. e7, 1998.

[20] T. F. Yeh, Y. J. Lin, H. C. Lin et al., "Outcomes at school age after postnatal dexamethasone therapy for lung disease of prematurity," The New England Journal of Medicine, vol. 350, no. 13, pp. 1304-1313, 2004.

[21] K. L. Watterberg and S. M. Scott, "Evidence of early adrenal insufficiency in babies who develop bronchopulmonary dysplasia," Pediatrics, vol. 95, no. 1, pp. 120-125, 1995.

[22] O. Peltoniemi, M. A. Kari, K. Heinonen et al., "Pretreatment cortisol values may predict responses to hydrocortisone administration for the prevention of bronchopulmonary dysplasia in high-risk infants," Journal of Pediatrics, vol. 146, no. 5, pp. 632-637, 2005.

[23] K. L. Watterberg, J. S. Gerdes, K. L. Gifford, and H. M. Lin, "Prophylaxis against early adrenal insufficiency to prevent chronic lung disease in premature infants," Pediatrics, vol. 104, no. 6, pp. 1258-1263, 1999.

[24] O. Baud, L. Foix-L'Helias, M. Kaminski et al., "Antenatal glucocorticoid treatment and cystic periventricular leukomalacia in very premature infants," The New England Journal of Medicine, vol. 341, no. 16, pp. 1190-1196, 1999.

[25] C. McEvoy, S. Bowling, K. Williamson, P. McGaw, and M. Durand, "Randomized, double-blinded trial of lowdose dexamethasone: II. Functional residual capacity and pulmonary outcome in very low birth weight infants at risk for bronchopulmonary dysplasia," Pediatric Pulmonology, vol. 38, no. 1, pp. 55-63, 2004.

[26] D. E. Odd, D. L. Armstrong, R. L. Teele, C. A. Kuschel, and J. E. Harding, "A randomized trial of two dexamethasone regimens to reduce side-effects in infants treated for chronic lung disease of prematurity," Journal of Paediatrics and Child Health, vol. 40, no. 5-6, pp. 282-289, 2004.

[27] C. A. Malloy, K. Hilal, Z. Rizvi, M. Weiss, and J. K. Muraskas, "A prospective, randomized, double-masked trial comparing low dose to conventional dose dexamethasone in neonatal chronic lung disease," Internet Journal of Pediatrics and Neonatology, vol. 5, no. 1, 2005.

[28] F. J. Walther, R. D. Findlay, and M. Durand, "Adrenal suppression and extubation rate after moderately early lowdose dexamethasone therapy in very preterm infants," Early Human Development, vol. 74, no. 1, pp. 37-45, 2003.

[29] E. Anttila, O. Peltoniemi, D. Haumont et al., "Early neonatal dexamethasone treatment for prevention of bronchopulmonary dysplasia: randomised trial and meta-analysis evaluating 
the duration of dexamethasone therapy," European Journal of Pediatrics, vol. 164, no. 8, pp. 472-478, 2005.

[30] L. W. Doyle, P. G. Davis, C. J. Morley et al., "Low-dose dexamethasone facilitates extubation among chronically ventilatordependent infants: a multicenter, international, randomized, controlled trial," Pediatrics, vol. 117, no. 1, pp. 75-83, 2006.

[31] H. J. Rozycki, P. R. Byron, G. R. Elliott, T. Carroll, and G. R. Gutcher, "Randomized controlled trial of three different doses of aerosol beclomethasone versus systemic dexamethasone to promote extubation in ventilated premature infants," Pediatric Pulmonology, vol. 35, no. 5, pp. 375-383, 2003.

[32] B. H. Lee, B. J. Stoll, S. A. McDonald, and R. D. Higgins, "Adverse neonatal outcomes associated with antenatal dexamethasone versus antenatal betamethasone," Pediatrics, vol. 117, no. 5, pp. 1503-1510, 2006.

[33] M. DeCastro, N. El-Khoury, L. Parton, P. Ballabh, and E. F. LaGamma, "Postnatal betamethasone vs dexamethasone in premature infants with bronchopulmonary dysplasia: a pilot study," Journal of Perinatology, vol. 29, no. 4, pp. 297-304, 2009.

[34] C. O'Callaghan, J. Hardy, J. Stammers, T. J. Stephenson, and D. Hull, "Evaluation of techniques for delivery of steroids to lungs of neonates using a rabbit model," Archives of Disease in Childhood, vol. 67, no. 1, pp. 20-24, 1992.

[35] T. F. Fok, S. Monkman, M. Dolovich et al., "Efficiency of aerosol medication delivery from a metered dose inhaler versus jet nebulizer in infants with bronchopulmonary dysplasia," Pediatric Pulmonology, vol. 21, no. 5, pp. 301-309, 1996.

[36] M. A. Dugas, D. Nguyen, L. Frenette et al., "Fluticasone inhalation in moderate cases of bronchopulmonary dysplasia," Pediatrics, vol. 115, no. 5, pp. e566-e572, 2005.

[37] S. Arnon, J. Grigg, and M. Silverman, "Effectiveness of budesonide aerosol in ventilator-dependent preterm babies: a preliminary report," Pediatric Pulmonology, vol. 21, no. 4, pp. 231-235, 1996.

[38] C. H. Cole, T. Colton, B. L. Shah et al., "Early inhaled glucocorticoid therapy to prevent bronchopulmonary dysplasia," The New England Journal of Medicine, vol. 340, no. 13, pp. 1005-1010, 1999.

[39] T. F. Yeh, H. C. Lin, C. H. Chang et al., "Early intratracheal instillation of budesonide using surfactant as a vehicle to prevent chronic lung disease in preterm infants: a pilot study," Pediatrics, vol. 121, no. 5, pp. e1310-e1318, 2008.

[40] D. L. Armstrong, J. Penrice, F. H. Bloomfield, D. B. Knight, J. A. Dezoete, and J. E. Harding, "Follow up of a randomised trial of two different courses of dexamethasone for preterm babies at risk of chronic lung disease," Archives of Disease in Childhood, vol. 86, no. 2, pp. F102-F107, 2002.

[41] L. W. Doyle, P. G. Davis, C. J. Morley et al., "DART Study Investigators. Outcome at 2 years of age of infants from the DART study: a multicenter, international, randomized, controlled trial of low-dose dexamethasone," Pediatrics, vol. 119, no. 4, pp. 716-721, 2007.

[42] A. R. Stark, W. Carlo, B. R. Vohr et al., "NICHD Neonatal Research Network. Neurodevelopmental outcome and growth at 18-22 months [abstract]," Pediatric Research, vol. 49, p. 388 A, 2001.

[43] C. Romagnoli, E. Zecca, R. Luciano, G. Torrioli, and G. Tortorolo, "A three year follow up of preterm infants after moderately early treatment with dexamethasone," Archives of Disease in Childhood, vol. 87, no. 1, pp. F55-F58, 2002.
[44] T. T. Wilson, L. Waters, C. C. Patterson et al., "Neurodevelopmental and respiratory follow-up results at 7 years for children from the United Kingdom and Ireland enrolled in a randomized trial of early and late postnatal corticosteroid treatment, systemic and inhaled. The Open Study of Early Corticosteroid Treatment," Pediatrics, vol. 117, no. 6, pp. 2196-2205, 2006.

[45] T. F. Yeh, Y. J. Lin, H. C. Lin et al., "Outcomes at school age after postnatal dexamethasone therapy for lung disease of prematurity," The New England Journal of Medicine, vol. 350, no. 13, pp. 1304-1313, 2004.

[46] T. M. O'Shea, L. K. Washburn, P. A. Nixon, and D. J. Goldstein, "Follow-up of a randomized, placebo-controlled trial of dexamethasone to decrease the duration of ventilator dependency in very low birth weight infants: neurodevelopmental outcomes at 4 to 11 years of age," Pediatrics, vol. 120, no. 3, pp. 594-602, 2007.

[47] S. J. Gross, R. D. Anbar, and B. B. Mettelman, "Follow-up at 15 years of preterm infants from a controlled trial of moderately early dexamethasone for the prevention of chronic lung disease," Pediatrics, vol. 115, no. 3, pp. 681-687, 2005.

[48] R. A. K. Jones, "Randomized, controlled trial of dexamethasone in neonatal chronic lung disease: 13- to 17-year follow-up study: I. Neurologic, psychological, and educational outcomes," Pediatrics, vol. 116, no. 2, pp. 370-378, 2005.

[49] K. L. Watterberg, J. S. Gerdes, K. L. Gifford, and H. M. Lin, "Prophylaxis against early adrenal insufficiency to prevent chronic lung disease in premature infants," Pediatrics, vol. 104, no. 6, pp. 1258-1263, 1999.

[50] K. L. Watterberg, J. S. Gerdes, C. H. Cole et al., "Prophylaxis of early adrenal insufficiency to prevent bronchopulmonary dysplasia: a multicenter trial," Pediatrics, vol. 114, no. 6, pp. 1649-1657, 2004.

[51] O. Peltoniemi, M. A. Kari, K. Heinonen et al., "Pretreatment cortisol values may predict responses to hydrocortisone administration for the prevention of bronchopulmonary dysplasia in high-risk infants," Journal of Pediatrics, vol. 146, no. 5, pp. 632-637, 2005.

[52] F. Bonsante, G. Latorre, S. Iacobelli et al., "Early low-dose hydrocortisone in very preterm infants: a randomized, placebo-controlled trial," Neonatology, vol. 91, no. 4, pp. 217-221, 2007.

[53] K. J. Barrington, "The adverse neurodevelopmental effects of postnatal steroids in the preterm infant: a systematic review of RCTs," BMC Pediatrics, vol. 1, article 1, 2001.

[54] H. L. Halliday, R. A. Ehrenkranz, and L. W. Doyle, "Early postnatal ( $<96$ hours) corticosteroids for preventing chronic lung disease in preterm infants," Cochrane Database of Systematic Reviews, no. 1, p. CD001146, 2003.

[55] H. L. Halliday, R. A. Ehrenkranz, and L. W. Doyle, "Moderately early (7-14 days) postnatal corticosteroids for preventing chronic lung disease in preterm infants," Cochrane Database of Systematic Reviews, no. 1, p. CD001144, 2003.

[56] H. L. Halliday, R. A. Ehrenkranz, and L. W. Doyle, "Delayed (>3 weeks) postnatal corticosteroids for chronic lung disease in preterm infants," Cochrane Database of Systematic Reviews, no. 1, p. CD001145, 2003.

[57] H. L. Halliday, R. A. Ehrenkranz, and L. W. Doyle, "Early (< 8 days) postnatal corticosteroids for preventing chronic lung disease in preterm infants," Cochrane Database of Systematic Reviews, no. 1, p. CD001146, 2009.

[58] H. L. Halliday, R. A. Ehrenkranz, and L. W. Doyle, "Late ( $>7$ days) postnatal corticosteroids for chronic lung disease in preterm infants," Cochrane Database of Systematic Reviews, no. 1, p. CD001145, 2009. 
[59] L. W. Doyle, H. L. Halliday, R. A. Ehrenkranz, P. G. Davis, and J. C. Sinclair, "Impact of postnatal systemic corticosteroids on mortality and cerebral palsy in preterm infants: effect modification by risk for chronic lung disease," Pediatrics, vol. 115, no. 3, pp. 655-661, 2005.

[60] W. Onland, M. Offringa, A. P. D. Jaegere, and A. H. van Kaam, "Finding the optimal postnatal dexamethasone regimen for preterm infants at risk of bronchopulmonary dysplasia: a systematic review of placebo-controlled trials," Pediatrics, vol. 123, no. 1, pp. 367-377, 2009.

[61] D. Wilson-Costello, M. C. Walsh, J. C. Langer et al., "Eunice Kennedy Shriver National Institute of Child Health and Human Development Neonatal Research Network. Impact of postnatal corticosteroid use on neurodevelopment at 18 to 22 months' adjusted age: effects of dose, timing, and risk of bronchopulmonary dysplasia in extremely low birth weight infants," Pediatrics, vol. 123, pp. e430-e437, 2009.

[62] B. P. Murphy, T. E. Inder, P. S. Huppi et al., "Impaired cerebral cortical gray matter growth after treatment with dexamethasone for neonatal chronic lung disease," Pediatrics, vol. 107, no. 2, pp. 217-221, 2001.

[63] N. A. Parikh, R. E. Lasky, K. A. Kennedy et al., "Postnatal dexamethasone therapy and cerebral tissue volumes in extremely low birth weight infants," Pediatrics, vol. 119, no. 2, pp. 265-272, 2007.

[64] T. M. O’Shea, J. M. Kothadia, K. L. Klinepeter et al., "Randomized placebo-controlled trial of a 42-day tapering course of dexamethasone to reduce the duration of ventilator dependency in very low birth weight infants: outcome of study participants at 1-year adjusted age," Pediatrics, vol. 104, no. 1 I, pp. 15-21, 1999.

[65] M. W. Huysman, A. C. Hokken-Koelega, M. A. De Ridder, and P. J. Sauer, "Adrenal function in sick very preterm infants," Pediatric Research, vol. 48, no. 5, pp. 629-633, 2000.

[66] K. L. Watterberg, S. M. Scott, C. Backstrom, K. L. Gifford, and K. L. Cook, "Links between early adrenal function and respiratory outcome in preterm infants: airway inflammation and patent ductus arteriosus," Pediatrics, vol. 105, no. 2, pp. 320-324, 2000.

[67] K. L. Watterberg, J. S. Gerdes, and K. L. Cook, "Impaired glucocorticoid synthesis in premature infants developing chronic lung disease," Pediatric Research, vol. 50, no. 2, pp. 190-195, 2001.

[68] P. Nykänen, E. Anttila, K. Heinonen, M. Hallman, and R. Voutilainen, "Early hypoadrenalism in premature infants at risk for bronchopulmonary dysplasia or death," Acta Paediatrica, vol. 96, no. 11, pp. 1600-1605, 2007.

[69] J. S. Garland, C. P. Alex, T. H. Pauly et al., "A three-day course of dexamethasone therapy to prevent chronic lung disease in ventilated neonates: a randomized trial," Pediatrics, vol. 104, no. 1 I, pp. 91-99, 1999.

[70] A. R. Stark, W. A. Carlo, J. E. Tyson et al., "National Institute of Child Health and Human Development Neonatal Research Network. Adverse effects of early dexamethasone in extremely-low-birth-weight infants," The New England Journal of Medicine, vol. 344, pp. 95-101, 2001.

[71] K. L. Watterberg, M. L. Shaffer, M. J. Mishefske et al., "Growth and neurodevelopmental outcomes after early low-dose hydrocortisone treatment in extremely low birth weight infants," Pediatrics, vol. 120, no. 1, pp. 40-48, 2007.

[72] O. M. Peltoniemi, A. Lano, R. Puosi et al., "Trial of early neonatal hydrocortisone: two-year follow-up," Neonatology, vol. 95, no. 3, pp. 240-247, 2009.
[73] M. van Der Heide-Jalving, P. J. Kamphuis, M. J. van Der Laan et al., "Short- and long-term effects of neonatal glucocorticoid therapy: is hydrocortisone an alternative to dexamethasone?" Acta Paediatrica, vol. 92, no. 7, pp. 827-835, 2003.

[74] R. Karemaker, C. J. Heijnen, S. Veen et al., "Differences in behavioral outcome and motor development at school age after neonatal treatment for chronic lung disease with dexamethasone versus hydrocortisone," Pediatric Research, vol. 60, no. 6, pp. 745-750, 2006.

[75] G. A. Lodygensky, K. Rademaker, S. Zimine et al., "Structural and functional brain development after hydrocortisone treatment for neonatal chronic lung disease," Pediatrics, vol. 116, no. 1, pp. 1-7, 2005.

[76] K. J. Rademaker, C. S. Uiterwaal, F. Groenendaal et al., "Neonatal hydrocortisone treatment: neurodevelopmental outcome and MRI at school age in preterm-born children," Journal of Pediatrics, vol. 150, no. 4, pp. 351-357, 2007.

[77] K. J. Rademaker, M. Rijpert, C. S. P. M. Uiterwaal et al., "Neonatal hydrocortisone treatment related to ${ }^{1} \mathrm{H}-\mathrm{MRS}$ of the hippocampus and short-term memory at school age in preterm born children," Pediatric Research, vol. 59, no. 2, pp. 309-313, 2006.

[78] R. Karemaker, A. Kavelaars, M. T. Wolbeek et al., "Neonatal dexamethasone treatment for chronic lung disease of prematurity alters the hypothalamus-pituitary-adrenal axis and immune system activity at school age," Pediatrics, vol. 121, no. 4, pp. e870-e878, 2008.

[79] E. Howard, "Reductions in size and total DNA of cerebrum and cerebellum in adult mice after corticosterone treatment in infancy," Experimental Neurology, vol. 22, no. 2, pp. 191-208, 1968.

[80] E. Howard and J. A. Benjamins, "DNA, ganglioside and sulfatide in brains of rats given corticosterone in infancy, with an estimate of cell loss during development," Brain Research, vol. 92, no. 1, pp. 73-87, 1975.

[81] H. W. Taeusch Jr., N. S. Wang, and M. Baden, "A controlled trial of hydrocortisone therapy in infants with respiratory distress syndrome: II. Pathology," Pediatrics, vol. 52, no. 6, pp. 850-854, 1973.

[82] P. M. Fitzhardinge, A. Eisen, C. Lejtenyi, K. Metrakos, and M. Ramsay, "Sequelae of early steroid administration to the newborn infant," Pediatrics, vol. 53, no. 6, pp. 877-883, 1974.

[83] G. H. Williams and R. G. Dluhy, "Diseases of the adrenal cortex," in Harrison's Principles of Internal Medicine, A. S. Fauci, E. Braunwald, and K. J. Isselbacher, Eds., pp. 20352057, McGraw-Hill, New York, NY, USA, 14th edition, 1998.

[84] A. W. Meikle and F. H. Tyler, "Potency and duration of action of glucocorticoids: effects of hydrocortisone, prednisone and dexamethasone on human pituitary-adrenal function," The American Journal of Medicine, vol. 63, no. 2, pp. 200-207, 1977.

[85] P. S. Goldman-Rakic, "Development of cortical circuitry and cognitive function," Child Development, vol. 58, no. 3, pp. 601-622, 1987.

[86] E. B. Isaacs, A. Lucas, W. K. Chong et al., "Hippocampal volume and everyday memory in children of very low birth weight," Pediatric Research, vol. 47, no. 6, pp. 713-720, 2000.

[87] B. S. McEwen, "The brain is an important target of adrenal steroid actions: a comparison of synthetic and natural steroids," Annals of the New York Academy of Sciences, vol. 823, pp. 201-213, 1997.

[88] E. R. De Kloet, E. Vreugdenhil, M. S. Oitzl, and M. Joëls, "Brain corticosteroid receptor balance in health and disease," Endocrine Reviews, vol. 19, no. 3, pp. 269-301, 1998. 
[89] R. S. Sloviter, A. L. Sollas, and S. Neubort, "Hippocampal dentate granule cell degeneration after adrenalectomy in the rat is not reversed by dexamethasone," Brain Research, vol. 682, no. 1-2, pp. 227-230, 1995.

[90] A. H. Hassan, P. Von Rosenstiel, V. K. Patchev, F. Holsboer, and O. F. X. Almeida, "Exacerbation of apoptosis in the dentate gyrus of the aged rat by dexamethasone and the protective role of corticosterone," Experimental Neurology, vol. 140, no. 1, pp. 43-52, 1996.

[91] C. C. Huang, H. R. Lin, Y. C. Liang, and K. S. Hsu, "Effects of neonatal corticosteroid treatment on hippocampal synaptic function," Pediatric Research, vol. 62, no. 3, pp. 267-270, 2007.

[92] D. K. Thompson, S. J. Wood, L. W. Doyle et al., "Neonate hippocampal volumes: prematurity, perinatal predictors, and 2-year outcome," Annals of Neurology, vol. 63, no. 5, pp. 642-651, 2008.

[93] S. S. Shah, A. Ohlsson, H. Halliday, and V. S. Shah, "Inhaled versus systemic corticosteroids for the treatment of chronic lung disease in ventilated very low birth weight preterm infants," Cochrane Database of Systematic Reviews, no. 4, p. CD002057, 2007.

[94] V. Shah, A. Ohlsson, H. L. Halliday, and M. S. Dunn, "Early administration of inhaled corticosteroids for preventing chronic lung disease in ventilated very low birth weight preterm neonates," Cochrane Database of Systematic Reviews, no. 4, p. CD001969, 2007. 


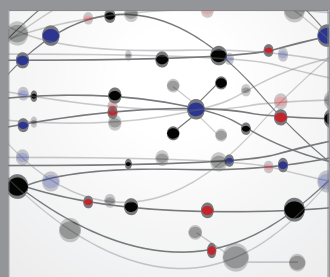

The Scientific World Journal
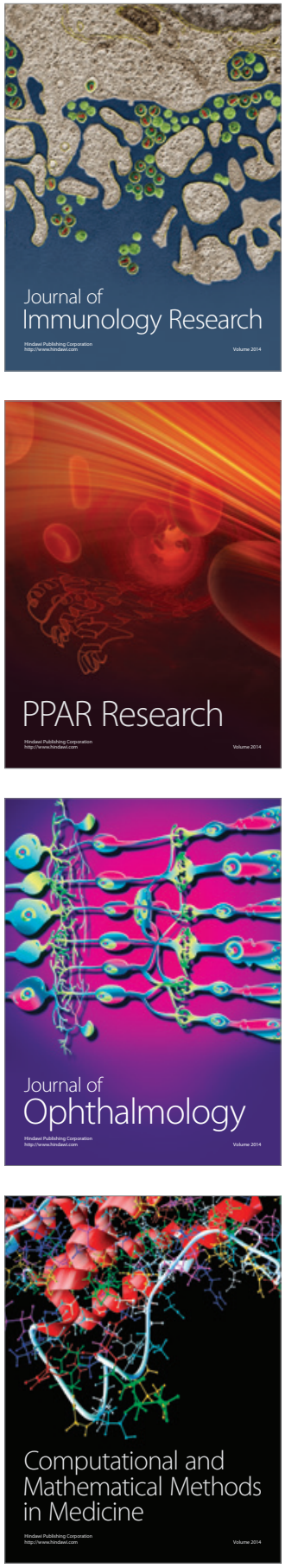

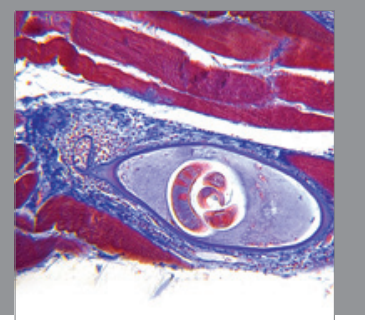

Gastroenterology

Research and Practice
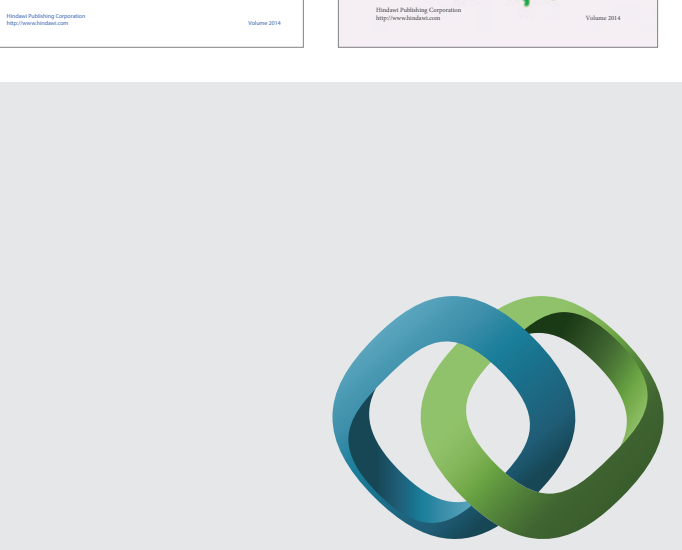

\section{Hindawi}

Submit your manuscripts at

http://www.hindawi.com
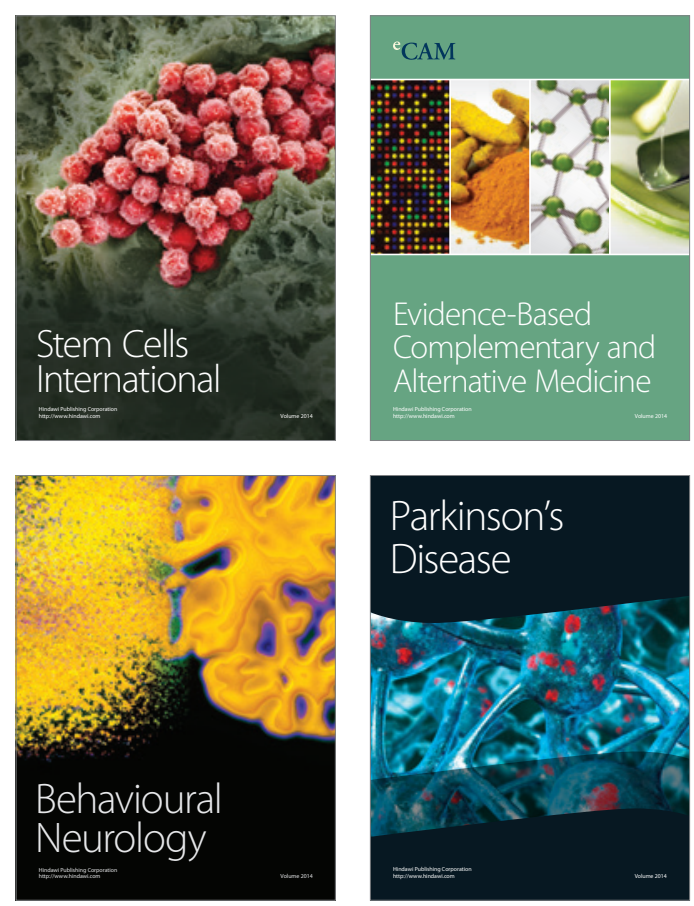

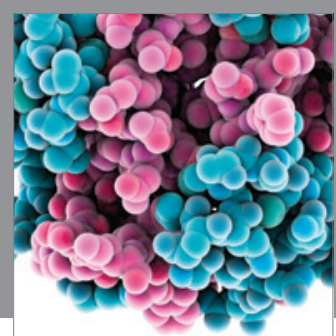

Journal of
Diabetes Research

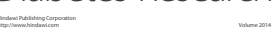

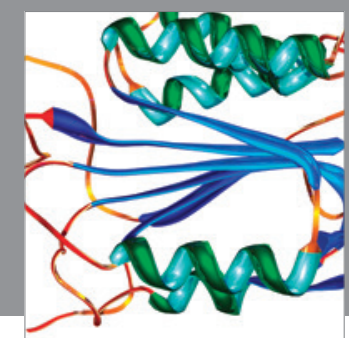

Disease Markers
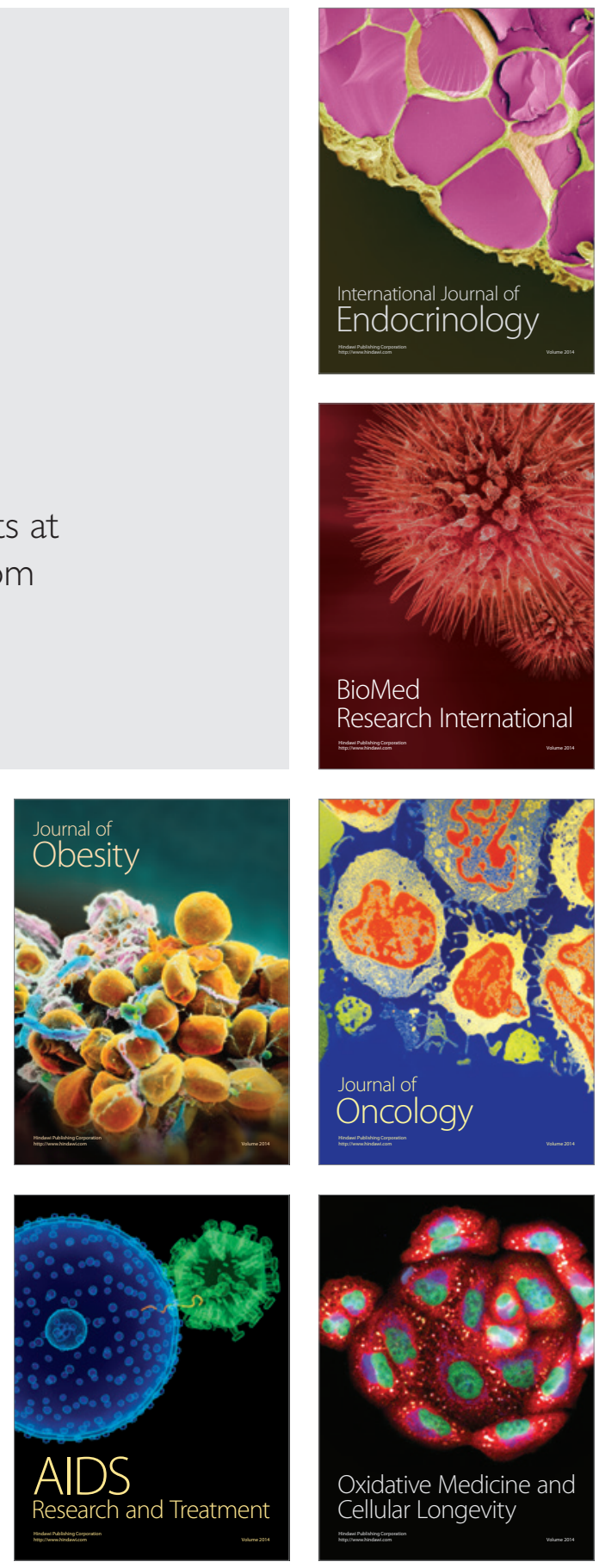